Publisher homepage: www.universepg.com, ISSN: 2663-6913 (Online) \& 2663-6905 (Print)

https://doi.org/10.34104/ajpab.020.01120120

American Journal of Pure and Applied Biosciences

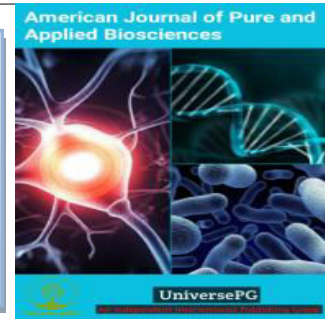

\title{
Optimization and Assessment of Different Parameters and Utilizing Food Waste from the College Canteen for Bioethanol Production
}

\author{
Sharif Neaz ${ }^{1 *}$, Sayeeda Monira Rahman ${ }^{2}$, S. M. Rafiq Bapari ${ }^{3}$, Hasib Uddin Ahmed Chowdhury Rumi ${ }^{4}$, \\ Abul Kaiser Bhuiyan ${ }^{5}$, and Sanjay Belowar ${ }^{6}$
}

${ }^{1}$ Dept. of Chemistry, Dhaka Commerce College, Dhaka, Bangladesh; ${ }^{2}$ Dept. of Biochemistry and Molecular Biology, Habibullah Bahar College, Dhaka, Bangladesh; ${ }^{3}$ Dept. of Biochemistry and Molecular Biology, Siddheswari College, Dhaka, Bangladesh; ${ }^{4}$ Dept. of Laboratory Medicine, Asgar Ali Hospital, 111/1/A Distillery Road, Gandaria, Dhaka, Bangladesh; ${ }^{5}$ Dept. of Biochemistry \& Immunology, Popular Diagnostic Centre Ltd. Dhaka, Bangladesh; ${ }^{6}$ Dept. of Chemistry, Bangladesh University of Engineering and Technology (BUET), Dhaka, Bangladesh.

*Correspondence: sharifneaz@gmail.com (Sharif Neaz, Assistant Professor and Chairman, Dept. of Chemistry, Dhaka Commerce College, Dhaka, Bangladesh).

\begin{abstract}
Bioethanol production from canteen food wastes not only resolves pollution issues by decreasing food waste management it also meets the requirement of bio-fuels. The development of alternatives to fossil fuels like biofuel is appropriate and increasingly urgent with the reduction of resources of fossil fuels and the progressively worsening situation of our atmosphere and natural surroundings. The usage of biofuels is one option to decrease the emission of greenhouse gases in the nearer future. Different promising raw materials have been considered for the production of bio-ethanol throughout the last few decades. Food waste from school and college canteens are increasing environmental problem. Food waste might be considered as an edible and nontoxic waste-derived during food production or consumption system. Food waste generated in canteens is rich in carbohydrate, which comprises $65 \%$ of total solids due to its high quantity of starch. Through the use of fermentation technology, this waste can be converted to useful by-products like bio-ethanol. Therefore, exploitation of hotel and restaurant food waste for bio-ethanol production can absolutely influence both the energy and environmental sustainability.
\end{abstract}

Keywords: Fossil fuels, Bioethanol, Canteen food waste, $\alpha$ - Amylase, Gluco-amylase, and S. cerevisiae.

\section{INTRODUCTION:}

For past few decades, the objectives to found national energy independence and to reduce the greenhouse gas emissions have led to the progress of renewable biofuel technologies based on agricultural materials. Ethanol is by far the most significant bio-fuel in the United States, accounting $94 \%$ of all bio-fuel production in 2012 (USDA, 2013). Ethanol is largely

UniversePG I www.universepg.com produced from corn in the U.S. and from sugar cane in Brazil (Walker et al., 2003). However, sugar cane and corn are used as food as well; excessive use of corn or sugar cane as feedstock for ethanol production results rivalry between food and fuel. In addition, rising prices of these two are the major drivers of the elevated cost of ethanol production. According to the earlier studies, cost of these sugar cane and corn feedstock contributed to $70-90 \%$ of the total ethanol production costs 
(McAloon et al., 2000; Kwiatkowski et al., 2000). Researchers have investigated the production of ethanol from low-cost agricultural wastes (Lau and Dale, 2009; Md et al., 2014), wheat straw (Saha et al., 2005), sugar cane bagasse (Martín et al., 2012), etc.

Proficiently producing sugars from cellulose and hemicellulose is the main challenges of using cellulosic biomass amongst others (Matsakas et al., 2014). To rupture cellulose and hemicellulose into monosaccharides, the biomass materials have to be processed with a harsh pretreatment process, followed by hydrolysis with the addition of a high dosage of enzymes, which significantly increases the capital and processing costs of the ethanol production (Humbird et al., 2014). Food waste is a complex biomass from households, restaurants, cafeterias, and groceries and contributes a considerable portion of municipal solid waste (Yan et al., 2012). Food waste management raises noteworthy environmental concerns. Disposal of food waste in landfill is not only expensive but also causing potential environmental problems; with direct and indirect emissions of greenhouse gases (Moon et al., 2009). Incinerations is another approach to manage food waste but is prohibited in different countries because of environmental concerns. Moreover, energy recovery through incineration may not be practicable, because of the evaporation of large water content in food waste results energy loss (Lin et al., 2013).

Food waste can be diverted from landfills and incinerators by turning it into compost to improve the soil fertility, but it may cause harsh pollution to surface and underground water (Uncu and Cekmecelioglu, 2011). Additionally, food waste contains abundant nourishment (starch, glucose, protein, etc.), making it a good raw material for bio-fuel production. At this time, most of the research has been focusing on the utilization of food waste to produce biogas through anaerobic digestion (Kim et al., 2013; Lee et al., 2013). Food waste can also be used as a low cost feedstock for producing ethanol (Lee et al., 2013), which is a more valuable fuel compared to biogas. It is noteworthy that higher solids contents of fermenting material can decrease the costs of ethanol production, since higher solid content results reduction of energy and water consumptions with the volumes of the processing equipment as well (Kim et al., 2013). Alternatively, fermentation of higher solids causes increased ethanol concentration, which in turn inhibits yeast activity, thus causing decreased ethanol production and lesser fermentation efficiency. In the vacuum fermentation system, a low ethanol concentration can be maintained in the fermenter during fermentation, thereby eliminating or minimizing yeast ethanol inhibition (Shihadeh et al., 2013; Mariano et al., 2011)

Uses of enzymes like $\alpha$ - Amylase and Gluco-amylase appreciably lessen the huge energy requirement and thus making the manufacturing process of starch-based products much straight-forward since there would be no call for liquefaction and saccharification (Wang et al., 2007; Yan et al., 2011). The energy input for starch liquefaction and saccharification represents about $30-40 \%$ of the total energy used during starchbased ethanol production (Sun et al., 2010). An additional research showed that competent application of raw starch-digesting enzyme during ethanol production results in significant reduction of about 10$20 \%$ fuel value in total ethanol product (Lee et al., 2012). The objective of this study was to fermentative production and separation of ethanol from food waste generated from a college canteen with high solids content. Food waste from canteens and hostels is an increasing environmental problem, particularly in hostel areas of school, colleges and universities. Canteen waste consists of canteen discards, waste from food preparation, large amounts of oils and fats. Food waste can be defined as any edible waste generated from food production, transportation, distribution and consumption.

\section{MATERIALS AND METHODS:}

Raw Material - Food waste used in this study was collecting from college canteens. First plastic, straws and toothpicks and paper were removed and then the samples. Since majority of food supplied from canteen are fast food, food wastes are mainly white bread buns of burgers, hot dogs etc. Breads were separated and chopped into small pieces (about $5 \times 5 \mathrm{~mm}$ ). The bread was dried in ambient conditions and partly powdered by a mortar and pestle. The crushed bread was afterward classified according to size by a mesh sieve, 
and mixed so the size distribution matches to that of flour. Then this coarse bread powder are stored for further use. Raw materials were analyzed for moisture, ash, crude fat, crude fiber, crude protein, and crude carbohydrate according to AOAC, (2000). The crude fiber, crude protein, and the fat content were subtracted from organic matter; the remainder accounted for carbohydrates: $\%$ carbohydrate $=100$-protein $(\%)+$ fat $(\%)+\operatorname{ash}(\%)$

Enzymes - Enzymes used in this research are $\alpha$ Amylase and Gluco-amylase. Alpha-amylase (EC 3.2.1.1) is an enzyme which catalyzes the hydrolysis of $\alpha$-1, 4-glycosidic bonds and $\alpha$-1, 6-glycosidic bonds of the inner branched chains of starch. This mainly causes the production of maltose, minor oligosaccharides, and dextrin (Sharma and Satyanarayana, 2013). On the other hand, Gluco-amylase (EC 3.2.1.3) enzyme mainly hydrolyzes $\alpha-1$, 4-glycosidic bonds from the non-reducing ends of starch chains, results the production of glucose molecules (Marín-Navarro and Polaina, 2011). Usually, conversion of starch to smaller oligosaccharides and monosaccharide glucose in industry comprises two steps which are energy demanding liquefaction step and saccharification step (Uddin et al., 2017). This saccharification step involves hydrolysis by $\alpha$-amylase and Gluco-amylase under high temperature conditions. During primary liquefaction step, starch is gelatinized first and then converted to dextrin and other minor oligosaccharide molecules by $\alpha$-amylase enzyme at high temperature $\left(95-105^{\circ} \mathrm{C}\right)$ and $\mathrm{pH}$ is maintained within 6.0 to 6.5 . Then in the saccharification step, the liquid starch slurry is cooled first and the $\mathrm{pH}$ is maintained from 4.0 to 4.5. Gluco-amylase is added further in the medium to hydrolyze the oligosaccharides to glucose at temperatures of $60-65^{\circ} \mathrm{C}$.

The food waste is collected from canteens. Initially 250 gram of food waste was taken which was crushed with blend in a blender and distilled water was added into the mash. After the pretreatment process enzymatic hydrolysis is done to convert the Starch to fermentable sugars. It was treated with $\alpha$-Amylase at $90^{\circ} \mathrm{C}, \mathrm{P}^{\mathrm{H}} 6.5$ for 2 hours and then hydrolysed by gluco-amylase at $40{ }^{\circ} \mathrm{C}, \mathrm{P}^{\mathrm{H}} 4.8$ for 2 hours. This hydrolysate is then subjected to autoclave for $15 \mathrm{~min}$ at $121^{\circ} \mathrm{C}$ and 15 psi. After the enzymatic digestion, the samples were inoculated with Saccharomyces cerevisiae (Baker yeast) inoculums collected from local store. The inoculums broth was prepared by introducing $0.8 \mathrm{~g}$ dry yeast in $10 \mathrm{ml}$ distilled water. Fermentation was conducted for $72 \mathrm{~h}$ at $32{ }^{\circ} \mathrm{C}$ with continuous agitation at $30 \mathrm{rpm}$. Hydrolysis gradually reduced the slurry viscosity, thus causing an increase in revolutions per minute ( $\mathrm{rpm})$ of the agitator higher than 30. Therefore, the agitation rate was checked and manually reset to $30 \mathrm{rpm}$ after each sampling.

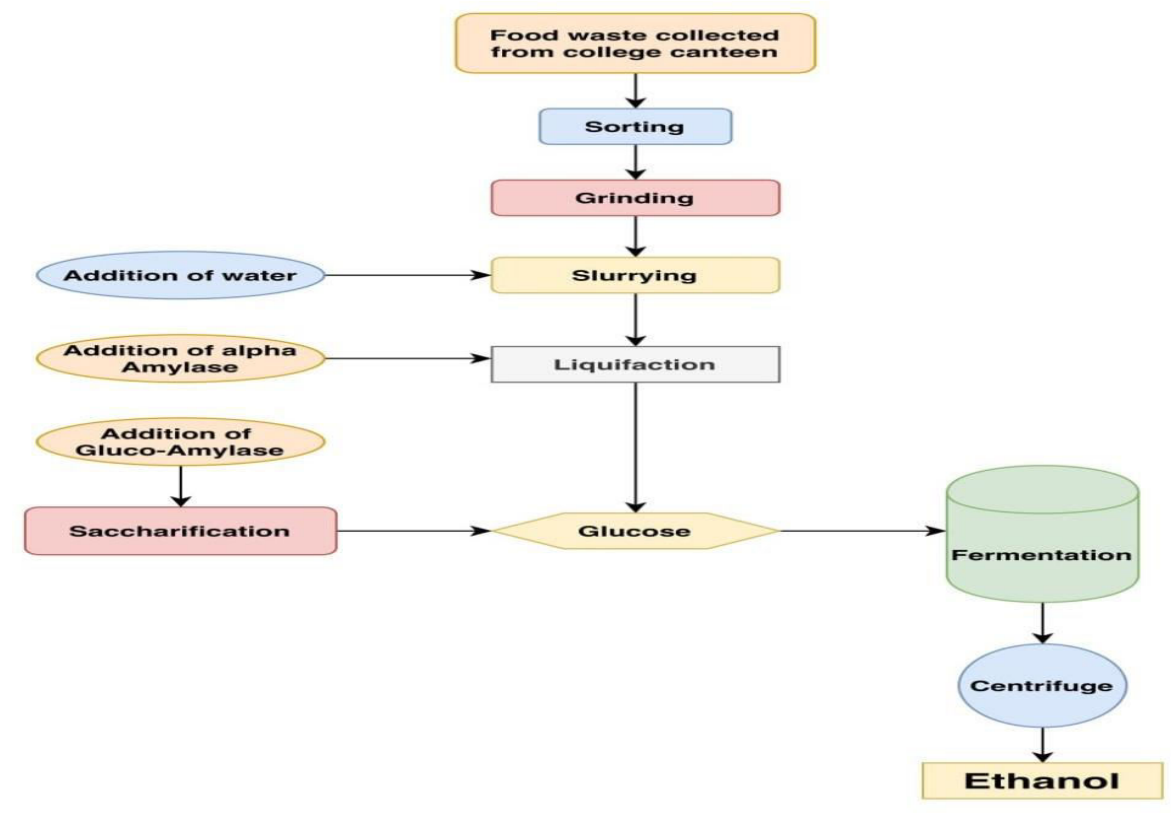

Fig 1: Schematic diagram of production of bio-ethanol from canteen food waste. 
Fermentation was monitored by taking $10 \mathrm{~mL}$ of slurry sample at 24,48 , and $72 \mathrm{~h}$ and centrifuged at $5000 \mathrm{rpm}$ for $30 \mathrm{~min}$ at $10{ }^{\circ} \mathrm{C}$ and the supernatant was used to estimate the glucose and ethanol concentration. Glucose content was determined according to the method of Miller. The reducing sugars produced from these reactions were evaluated by using conventional 3, 5-dinitrosalicylic acid (DNS) method, using glucose as standard. In this method 3 milliliters of DNS reagent is added to $3 \mathrm{ml}$ of glucose sample in a test tube and mixed thoroughly. The absorbance of resulting mixture was measured by an UV-vis spectrophotometer at $575 \mathrm{~nm}$. Ethanol concentration is determined according to the method of Williams and Darwin (Vamadevan and Bertoft, 2015). At first is 1 $\mathrm{g}$ of potassium dichromate in concentrated $(6 \mathrm{~N})$ sulfuric acid is dissolved properly to prepare $100 \mathrm{ml}$ of potassium dichromate reagent solution. Then by dissolving $1 \mathrm{~g}$ of S- Diphenylcarbazide to $1 \mathrm{ml}$ of $95 \%$ ethanol saturated S- Diphenylcarbazide solution is prepared. The combination is then added with $1 \mathrm{ml}$ of a $40 \%$ potassium sodium tartrate (Rochelle salt) solution to stabilize the color. The absorbance of colored solution was evaluated at $575 \mathrm{~nm}$ by an UVvis spectrophotometer. The absorbance values were compared to the ethanol standard graph and the percentage of ethanol had been calculated. Then fractional distillation was done to separate ethanol from the broth. Samples given feasible results in the colorimetric test were distilled and the percentages of ethanol in the distillates were determined.

\section{RESULT:}

In this present work, it has been showed that ethanol can be produced from college canteen bread waste. Therefore other studies should be done to check the efficiency of ethanol production from these products of the canteen bread waste by taking different parameters in consideration. Waste bread is very nutritious food waste which is rich in organic carbon and nitrogen and can be used for fermentation. Proximate analysis of waste bread from college canteen is given in Fig 2.

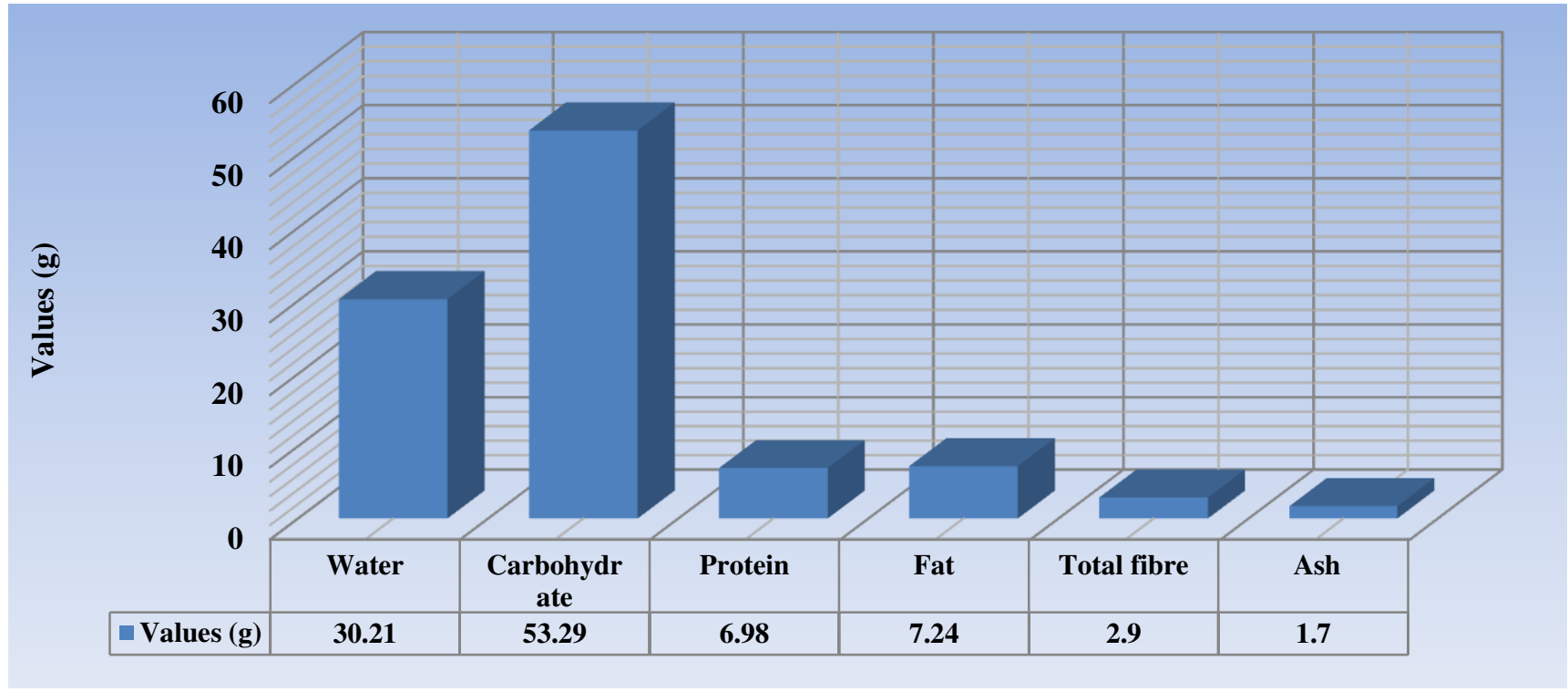

Fig 2: Proximate composition of waste bread.

The effect of different parameters on the production of ethanol from college canteen bread waste are presented below -

\section{Effect of time on production of reducing sugar -} Effect of fermentation time on the production of reducing sugar was studied. The isolate was grown on waste bread medium, at different incubation period $(0$, UniversePG I www.universepg.com
24, 48 and 72) hours at $\mathrm{P}^{\mathrm{H}} 5.0$ and $30^{\circ} \mathrm{C}$ in shaker incubator at $30 \mathrm{rpm}$ (Fig 3).

Effect of fermentation time on Ethanol production

- Effects of time on production of ethanol was studied by inoculating waste bread medium with Saccharomyces cerevisiae (Baker yeast) inoculums, at 
different incubation period $(0,24,48$ and 72$) \mathrm{hr}$ at $\mathrm{P}^{\mathrm{H}}$ 5.0 and $30^{\circ} \mathrm{C}$ in shaker incubator at $30 \mathrm{rpm}$. Ethanol was monitored by taking $10 \mathrm{~mL}$ of slurry sample at
24, 48, and $72 \mathrm{~h}$ and subjected to centrifuge at 5000 rpm for $30 \mathrm{~min}$ at $10{ }^{\circ} \mathrm{C}$ and the supernatant was used to estimate the concentration (Fig 4)

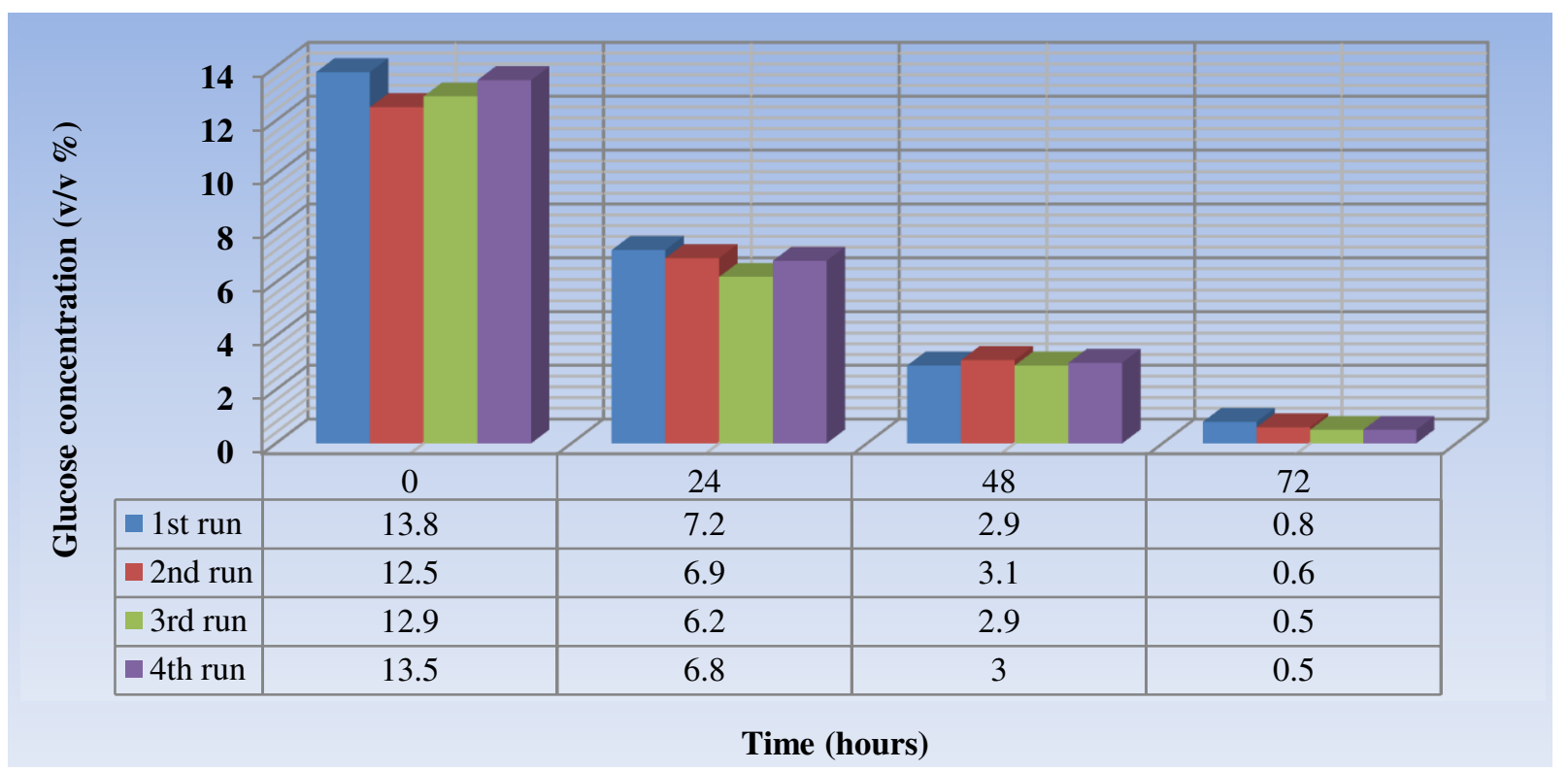

Fig 3: Glucose concentration at different time intervals.

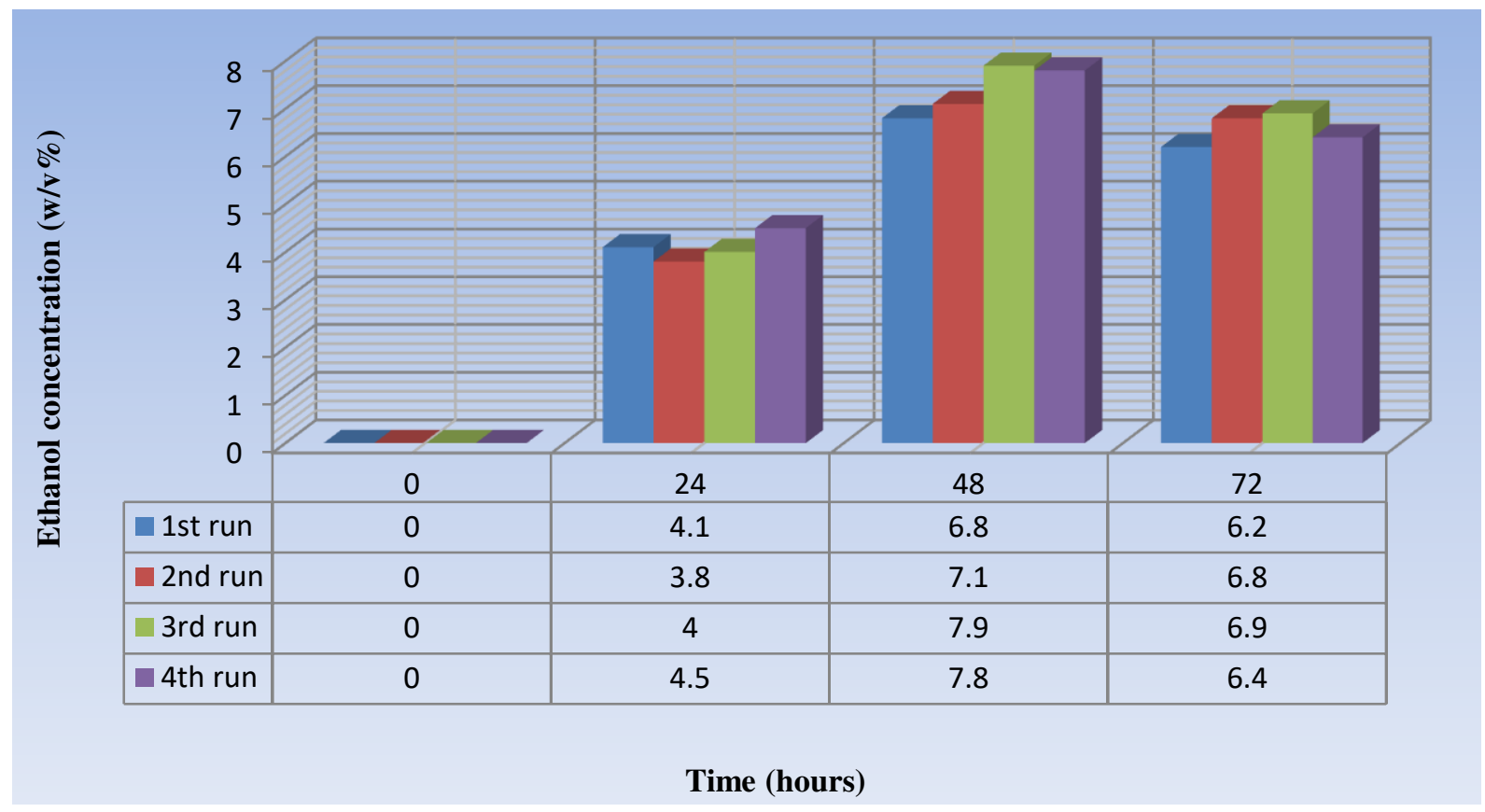

Fig 4: Ethanol concentration at different time intervals.

Effect of temperature - Temperature plays an important part in ethanol production, since increase of temperature causes the increase of the rate of alcoholic fermentation. The optimum temperature of ethanol ranges between $30^{\circ} \mathrm{C}$ to $40^{\circ} \mathrm{C}$ which depends on room temperature.
Effect of $\mathbf{P}^{\mathbf{H}-} \mathrm{P}^{\mathrm{H}}$ value plays significant contribution on alcoholic fermentation. The $\mathrm{pH}$ of ethanol ranges from 4 to 6 . Yeast generally tolerates slightly acidic environment from $\mathrm{P}^{\mathrm{H}} 4$ to 6 . In this research ethanol produced from bread wastes had elevated alcoholic content when the $\mathrm{P}^{\mathrm{H}}$ is 5.0. 
Table 1: Effect of Temperature \& Ethanol Concentration (v/v \%).

\begin{tabular}{|c|c|}
\hline Temperature & Ethanol Concentration (v/v \%) \\
\hline 30 & 5.1 \\
\hline 32 & 6.2 \\
\hline 34 & 7.8 \\
\hline 36 & 5.6 \\
\hline
\end{tabular}

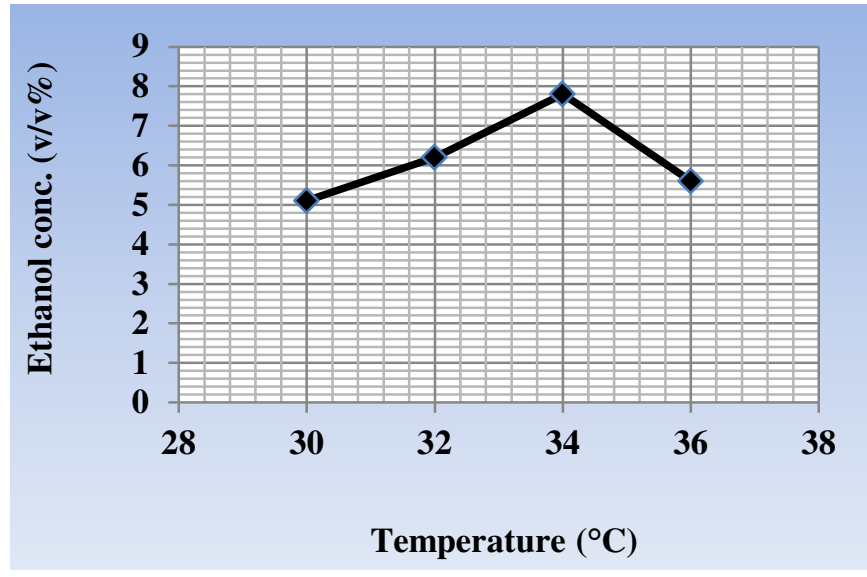

Fig 5: Temperature \& Ethanol Concentration (v/v \%).

Table 2: Effect of PH \& Ethanol concentration (v/v \%).

\begin{tabular}{|c|c|}
\hline $\mathbf{P}^{\mathbf{H}}$ & Ethanol Concentration (v/v \%) \\
\hline 4 & 3.1 \\
\hline 4.5 & 4.9 \\
\hline 5 & 7.8 \\
\hline 5.5 & 6.1 \\
\hline 6 & 4.2 \\
\hline
\end{tabular}

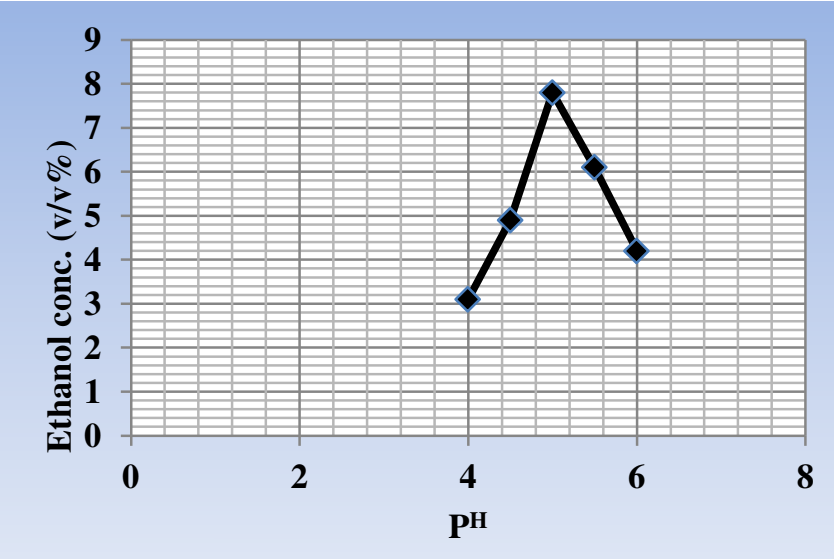

Fig 6: $\mathrm{PH}$ and Ethanol concentration (v/v \%).

\section{DISCUSSION:}

Starch is one of the most plentiful carbohydrate reserves among a variety of plants, such as tuberous plants, cereals and legumes etc. Starches are a polymer of glucose, which is mostly, consists of amylose and amylopectin. Amylose is a typically linear molecule containing $\alpha$-D glucosyl residues which are linked by $\alpha-1$, 4-glycosidic linkages, whereas amylopectin is a extremely branched structure composed of long polymers of $\alpha-1$, 4glycosidic bonds linked $\alpha$-D glucosyl units with $\alpha-1$, 6-linked side chains (Waterschoot et al., 2015). These amyloses can be used to produce many valuable food products in the food processing industry, such as maltose, glucose, fructose, glucose-fructose syrups, organic acids, amino acids, etc (Favarot et al., 2015).

Additionally, starch is also considered as feedstock in the fermentation industry for production of ethanol, which can be used as beverages or as biofuel (Favarot et al., 2015). Although alcohol making is a potential choice for food waste utilization, there are several research gaps and constraints that must be addressed to further extension of the technology. There is a huge demand to develop energy efficient recovery techniques to get improved alcohol production from food and food derived wastes now a day. There is also a requirement to optimize a cheaper and efficient pretreatment method to recover highest amount of fermentable carbohydrates from food or food derived wastes. It would be helpful to build up a co-fermentation process to employ food wastes while there is a growing demand for emerging technologies and cheaper raw materials which are essential to link this gap. Furthermore, it is not easy to meet a noteworthy portion of fuel demand with existing alcohol production potential of food waste. In this regard, use of food wastes in manufacture of alcohols for industrial, educational and medical applications may be a more constructive option to think about.

\section{COCLUSION:}

The result of this study has shown that effect of different parameters on the production of bioethanol. From this study, it is clear that the 
maximum yield of ethanol was obtained at temperature $34^{\circ} \mathrm{C} ; \mathrm{P}^{\mathrm{H}}$ 5.0. From this study we conclude that the process is cheaper than the others because the raw materials used in this procedure comes from waste and does not produce any toxic residues during the process. This bio-ethanol production process can be used for small and large scale plant because carbohydrate based food waste can be obtained from school, college and university canteens continuously. It is also noteworthy that, results were derived from limited parameters and only a single isolate of microorganism was employed in this study. More studies should be done to elaborate the characteristics of fermentation and compare those parameters to develop a procedure to get more bio-ethanol from canteen waste fermentation. This study was intended towards fermentation and optimization only. An inexpensive, effective downstream processing scheme of the ethanol generated in this procedure also requires further development.

\section{ACKNOWLEDGEMENT:}

The authors show their gratitude to Dept. of Chemistry, Dhaka Commerce College, Bangladesh for allowing carrying out this research. They are also thankful to Dept. of Chemistry, Dhaka Commerce College, Bangladesh for the contribution at different stages in this study.

\section{CONFLICT OF INTERESTS:}

The authors declared no potential conflicts of the interest with respect to the research, authorship of this article.

\section{REFERENCES:}

1. AOAC, (2000). Official Methods of Analysis. $17^{\text {th }}$ Edition, The Association of Official Analytical Chemists, Gaithersburg, MD, USA. Methods 925.10, 65.17, 974.24, 992.16.

2. Favaro L, Viktor MJ, Rose SH, and Casella S. (2015). Consolidated bioprocessing of starchy substrates into ethanol by industrial Saccharomyces cerevisiae strains secreting fungal amylases. Biotechnol Bioeng. 112:1751-60.

https://doi.org/10.1002/bit.25591

3. Humbird, D.; Davis, R.; Tao, L.; and Worley, M. (2011). Process Design and Economics for Biochemical Conversion of Lignocellulosic Biomass to Ethanol; National Renewable Energy Laboratory, Golden, CO, NREL/TP-5100-47764. http://www.nrel.gov/docs/fy11osti/47764.pdf

4. Kim, J. K.; Oh, B. R.; Chun, Y. N.; Kim, S. W. (2006). Effects of temperature and hydraulic retention time on anaerobic digestion of food waste. J. Biosci. Bioeng. 102, 328-332.

5. Kim, J. H.; Lee, J. C.; Pak, D. (2011) Feasibility of producing ethanol from food waste. Waste Manage. 31, 2121-2125. https://doi.org/10.1016/j.wasman.2011.04.011

6. Kwiatkowski, J. R.; McAloon, A. J.; Taylor, F.; Johnston, D. B. (2006). Modeling the process and costs of fuel ethanol production by the corn dry-grind process. Ind. Crops Prod. 23, 288-296.

7. Lau, M. W.; Dale, B. E. (2009). Cellulosic ethanol production from AFEX-treated corn stover using Saccharomyces cerevisiae 424A (LNHST). Proc. Natl. Acad. Sci. USA. 106, 1368-1373. https://doi.org/10.1073/pnas.0812364106

8. Lee, D.-Y.; Ebie, Y.; Xu, K.-Q.; Li, Y.-Y.; Inamori, Y. (2010). Continuous $\mathrm{H} 2$ and $\mathrm{CH} 4$ production from high-solid food waste in the two-stage thermophilic fermentation process with the recirculation of digester sludge. Bioresour. Technol. 101, S42-S47.

9. Lee W-S, Chen I-C, Chang C-H, Yang S-S. (2012). Bioethanol production from sweet potato by co-immobilization of saccharolytic molds and Saccharomyces cerevisiae. Renew Energ. 39: 216-22. https://doi.org/10.24297/jbt.v6i1.4016

10. Lin, C. S. K.; Pfaltzgraff, L. A.; HerreroDavila, and Dickson, F. (2013). Food waste as a valuable resource for the production of chemicals, materials and fuels. Current 
situation and global perspective. Energy Environ. Sci. 6, 426-464.

11. Mariano, A. P.; Qureshi, N.; Ezeji, T. C. (2011). Bioproduction of butanol in bioreactors: New insights from simultaneous in situ butanol recovery to eliminate product toxicity. Biotechnol. Bioeng. 108, 17571765. https://doi.org/10.1002/bit.23123

12. Martín, C.; Galbe, M.; Wahlbom, C. F.; Hahn-Hägerdal, B.; Jönsson, L. J. (2002). Ethanol production from enzymatic hydrolysates of sugarcane bagasse using recombinant xylose-utilising Saccharomyces cerevisiae. Enzyme Microb. Technol. 31, 274-282.

13. Marín-Navarro J, Polaina J. (2011). Glucoamylases: structural and biotechnological aspects. Appl Microbiol Biotechnol. 89: 1267-73. https://pubmed.ncbi.nlm.nih.gov/21152915/

14. Matsakas, L.; Kekos, D.; Loizidou, M.; Christakopoulos, P. (2014). Utilization of household food waste for the production of ethanol at high dry material content. Biotechnol. Biofuels. 7, 1-9.

15. McAloon, A.; Taylor, F.; Yee, W.; Ibsen, K.; Wooley, R. (2000). Determining the Cost of Producing Ethanol from Corn Starch and Lignocellulosic Feedstocks; National Renewable Energy Laboratory (NREL): Golden, CO, NREL/TP-580-28893, http://www.nrel.gov/docs/fy01osti/28893.pdf

16. Md. Ekhlas Uddin, Pulak Maitra, Hossain Md. Faruquee, Md. Firoz Alam, (2014). Isolation and characterization of proteases enzyme from locally isolated Bacillus sp., American J. of Life Sciences. 2(6), 338-344. https://doi.org/10.11648/j.ajls.20140206.1

17. Moon, H. C.; Song, I. S.; Kim, J. C.; Shirai, Y.; Lee, D. H.; Kim, J. K.; Chung, S. O.; Kim, D. H.; Oh, K. K.; and Cho, Y. S. (2009). Enzymatic hydrolysis of food waste and ethanol fermentation. Int. J. Energy Res. 33, 164-172.

18. Saha, B. C.; Iten, L. B.; Cotta, M. A.; Wu, Y. V. (2005). Dilute acid pretreatment, enzymatic saccharification and fermentation of wheat straw to ethanol. Process Biochem. 40, 3693-3700. https://doi.org/10.1016/j.procbio.2005.04.006

19. Sharma A, Satyanarayana T. (2013) Microbial acid-stable $\alpha$-amylases: characteristics, genetic engineering and applications. Process Biochem. 48: 201-11.

20. Shihadeh, J. K.; Huang, H.; Rausch, K. D.; Tumbleson, M. E.; Singh, V. (2013). Design of a vacuum flashing system for high-solids fermentation of corn. Trans. ASABE, 56, 1441-1447. https://doi.org/10.13031/trans.56.10277

21. Sun H, Zhao P, Ge X, Xia Y, Hao Z, Liu J, Peng M. (2010) Recent advances in microbial raw starch degrading enzymes. Appl Biochem Biotechnol. 160: 988-1003.

22. Uddin M. E., Ahmad T., and Ahammed T. (2017). Thermotolerant extracellular proteases produced by Bacillus subtilis isolated from local soil that representing industrial applications. J. of Pure and Applied Microbiol. 11(2), 733-741. https://doi.org/10.22207/JPAM.11.2.12

23. Uncu, O. N.; Cekmecelioglu, D. (2011). Cost-effective approach to ethanol production and optimization by response surface methodology. Waste Manage. 31, 636-643.

24. United States Department of Agriculture (USDA), (2013). Bioenergy Statistics; USDA: Washington, D.C. http://www.ers.usda.gov/dataproducts/\%20usb ioenergy-statitics.aspx\#

25. Vamadevan V, Bertoft E. (2015). Structurefunction relationships of starch components. Starch/Stärke. 67: 55-68.

26. Walker, K.; Vadlani, P.; Madl, R.; Ugorowski, P.; Hohn, K. L. (2013). Ethanol fermentation from food processing waste. Environ. Prog. Sustainable Energy, 32, 1280-1283. https://doi.org/10.1002/ep.11700

27. Wang, P.; Singh, V.; Xue, H.; Johnston, D. B.; Rausch, K. D.; and Tumbleson, M. (2007). Comparison of raw starch hydrolyzing enzyme with conventional liquefaction and saccharification enzymes in dry-grind 
corn processing. Cereal Chem. 84, 10-14.

https://doi.org/10.1094/CCHEM-84-1-0010

28. Waterschoot J, Gomand SV, Fierens E, Delcour JA. (2015). Production, structure, physicochemical and functional properties of maize, cassava, wheat, potato and rice starches. Starch/Stärke. 67:14-29. https://doi.org/10.1002/star.201300238

29. Yan, S.; Li, J.; Chen, X.; Wu, J.; Wang, P.; Ye, J.; Yao, J. (2011). Enzymatical hydrolysis of food waste and ethanol production from the hydrolysate. Renewable Energy. 36, 1259-1265. https://doi.org/10.3390/su7021446

30. Yan, S.; Chen, X.; Wu, J.; Wang, P. (2012). Ethanol production from concentrated food waste hydrolysates with yeast cells immobilized on corn stalk. Appl. Microbiol. Biotechnol. 94, 829-838.

https://pubmed.ncbi.nlm.nih.gov/22395912/

Citation: Neaz S, Rahman SM, Bapari SMR, Rumi HUAC, Bhuiyan AK, and Belowar S. (2020). Optimization and assessment of different parameters and utilizing food waste from the college canteen for bioethanol production. Am. J. Pure Appl. Sci., 2(4), 112-120. https://doi.org/10.34104/ajpab.020.01120120 @) () 